This PDF is a selection from an out-of-print volume from the National Bureau of Economic Research

Volume Title: R\&D and Productivity: The Econometric Evidence

Volume Author/Editor: Zvi Griliches

Volume Publisher: University of Chicago Press

Volume ISBN: 0-226-30886-3

Volume URL: http://www.nber.org/books/gril98-1

Publication Date: January 1998

Chapter Title: Productivity, R\&D, and the Data Constraint

Chapter Author: Zvi Griliches

Chapter URL: http://www.nber.org/chapters/c8352

Chapter pages in book: (p. 347 - 374) 


\section{Productivity, R\&D, and the Data Constraint}

Forty years ago economists discovered the "residual." The main message of this literature, that growth in conventional inputs explains little of the observed growth in output, was first articulated by Solomon Fabricant in 1954 and emphasized further by Moses Abramovitz (1956), John Kendrick (1956), and Robert Solow (1957). ${ }^{1}$ The pioneers of this subject were quite clear that this finding of large residuals was an embarrassment, at best "a measure of our ignorance" (Abramovitz, 1956 p. 11). But by attributing it to technical change and other sources of improved efficiency they turned it, perhaps inadvertently, from a gap in our understanding into an intellectual asset, a method for measuring "technical change." Still, it was not a comfortable situation, and a subsequent literature developed trying to "explain" this residual, or more precisely, to attribute it to particular sources (Griliches, 1960, 1963a,b, 1964; Edward Denison, 1962; Dale Jorgenson and Griliches, 1967). The consensus of that literature was that, while measurement errors may play a significant role in such numbers, they could not really explain them away. The major sources of productivity growth were seen as coming from improvements in the quality of labor and capital and from other, not otherwise measured, sources of efficiency and technical change, the latter being in turn the product of formal and informal R\&D investments by individuals, firms, and governments, and of the largely unmeasured contributions of science and other spillovers. The prescrip-

Reprinted from the American Economic Review 84, no. 1 (March 1994): 1-23.

Presidential address delivered at the one hundred sixth meeting of the American Economic Association, January 4, 1994, Boston, MA.

I am indebted to many friends for comments on an earlier draft, and to the Bradley, Sloan, and National Science Foundations for the support of my work.

1. The message itself was not exactly new. With hindsight, it is visible in the earlier work of Jan Tinbergen (1942), George Stigler (1947), Glen Barton and Martin Cooper (1948), Jacob Schmookler (1952), and Vernon Ruttan $(1954,1956)$. See Griliches (1996) for a more detailed account of these developments. 
tion of additional investments in education, in science, and in industrial R\&D followed from this reading of history as did also the hope and expectation that the recently observed rates of "technical change" would continue into the future.

This general view of the sources of growth was put into doubt by the events of the 1970s and 1980s. Beginning in 1974 (or perhaps already in 1968) productivity growth slowed down significantly in the United States and abroad, and it has not fully recovered yet, at least as far as national aggregates are concerned. The many explanations that were offered for these events were not very convincing (see e.g., Denison, 1979; Martin Baily and Robert Gordon, 1988; Griliches, 1988). As time went on and the direct effects of the energyprice shocks wore off but the expected recovery did not come or came only weakly, more voices were heard arguing that the slowdown might not be temporary; that the energy-price shocks just revealed what was already there-a decline in the underlying trend of technical change in the world economy; that the growth opportunities that had opened up in the late 1930s and had been interrupted by World War II have been exhausted, reflecting perhaps the completion of an even longer cycle, going back to the beginnings of this century (see e.g., Alfred Kleinknecht, 1987; Gordon, 1993a). Even more ominously, the slowdown was blamed on diminishing returns to science and technology in general and on the onset of widespread socioeconomic sclerosis (see e.g., William Nordhaus, 1972, 1989; Mancur Olson, 1982; F. M. Scherer, 1983, 1986; Robert Evenson, 1984; Baily and A. K. Chakrabarti, 1988).

This is a rather pessimistic view of our current situation, and I would like to argue that the observed facts do not really support it. But that will not be easy, both because some of the "facts" are contradictory and because our measurement and observational tools are becoming increasingly inadequate in the context of our changing economy. Nevertheless, I will review some of the evidence for such views and argue with their interpretation. There are several possibilities here: (i) this view is true and that is sad; (ii) it is not true and recovery is around the corner if not already underway; (iii) it may be true, but whatever is or is not happening has little to do with diminishing returns to science or industrial R\&D. Or, (iv) it may be that we just do not know. As is the case with global warming, we may not have an adequate understanding of the mechanisms producing growth or adequate data to adjudicate whether there has or has not been an underlying trend shift. If that is true, as is most likely, the question arises as to why we don't know more after years of research done by so many good people. What is it about our data and data acquisition structure, and possibly also our intellectual framework, that prevents us from making more progress on this topic?

In discussing this range of topics, I will concentrate primarily on the $R \& D$ component of this story-not because it can explain much of the productivity slowdown (it cannot), and not just because this is where I have done most of my recent work, but because it illustrates rather well the major point I want to 
make here tonight: that our understanding of what is happening in our economy (and in the world economy) is constrained by the extent and quality of the available data. I will also allude briefly to similar issues which arise in interpreting the productivity contribution of computers in the economy. Parallel tales about data constraining our understanding could also be told about other potential productivity-slowdown villains: energy-price shocks, insufficient investment in physical capital, and possible declines in human-capital investments. Having reached the verdict of "not proven," largely on account of insufficient evidence, I shall make a number of more general remarks on the state of our data and the possible reasons for it. The major message that I will be trying to convey is that we often misinterpret the available data because of inadequate attention to how they are produced and that the same inattention by us to the sources of our data helps explain why progress is so slow. It is not just the measurement of productivity that is affected. Other fields of empirical economics are also struggling against the limitations imposed by the available data. Great advances have been made in theory and in econometric techniques, but these will be wasted unless they are applied to the right data.

\subsection{The "Facts"}

There are three sets of "facts" to look at: what has happened to productivity, what has happened to investment in R\&D and science, and what has happened to the relationship between them. Sometime in the late 1960s measured productivity growth in the United States started to slow down. After a mild recovery in the early 1970 s, the world economy was hit by two successive oil-price shocks which dropped economic growth rates in most of the developed economies to levels significantly below those experienced in the 1960s and early 1970s. While the effects of the oil-price shocks wore off and real energy prices declined to close to their earlier levels, productivity growth rates did not recover much. At this point, and also somewhat earlier, many observers started wondering whether something more fundamental than just an energy-priceshock-induced business cycle was afoot. Standing in the early 1980s and looking back at the recent past, one would have observed a decline in total patents granted in the United States beginning in the early 1970s and a decline in the share of GNP being devoted to industrial R\&D starting in the mid-1960s, the timing looking suspiciously appropriate for declining productivity growth rates 5-10 years later. One could also see a continuous and worrisome decline in the number of patents received per corporate R\&D dollar (see below). But there were also many other events clouding this picture, making one wonder whether faltering $R \& D$ and scientific efforts are really the culprits behind our current woes.

A number of discordant facts are important for an understanding of what happened. First, the productivity-growth decline in many other countries was larger, absolutely, than in the United States, and there it was not associated 


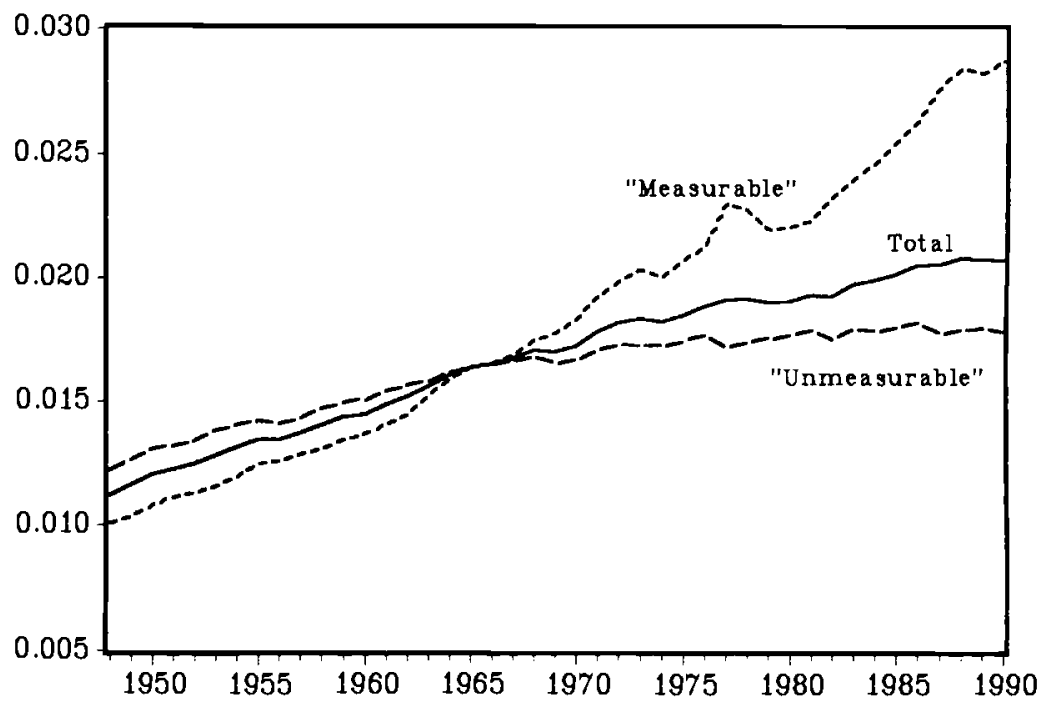

Fig. 14.1 Gross domestic product per man-hour (thousands of 1982 dollars, United States, 1948-1990)

Notes: Measurable sectors are agriculture, mining, manufacturing, transportation, communications, and public utilities; unmeasurable sectors are construction, trade, finance, other services, and government. Values for 1977-1987 are based on 1987 weights; values for 1948-1976 are based on 1982 weights (the series are linked at 1977).

with declines in R\&D investment. ${ }^{2}$ Second, as illustrated in Figure 14.1, the sectors where the productivity slowdown has persisted in the United States are largely outside of manufacturing, communications, and agriculture (see Gordon, 1987). Besides mining and public utilities, which were affected more specifically by the energy-price shocks, it has lingered particularly in construction, finance, and other services where output measurement is notoriously difficult. Third, the decline in patent grants in the 1970s was just a bureaucratic mirage, an example of fluctuations induced by changes in the data-generating process (a budgetary crisis in the Patent Office) rather than a reflection of the underlying activity itself. ${ }^{3}$ The number of patent applications did not decline significantly during this period, but also it did not grow. The latter fact, coupled with a continuous upward growth in the absolute level of company-financed $R \& D$, resulted in a persistent decline in the patents per $R \& D$ ratio in the United States (and also in most of the other countries for which we have data). This raised the specter of diminishing returns to $R \& D$ and offered the hypothe-

2. For example, the rate of growth in total factor productivity declined between the $1960 \mathrm{~s}$ and the 1970 s by 4.5 percent in Japan, 3.3 percent in France, and "only" 2 percent in the United States (see Organization for Economic Cooperation and Development, 1993).

3. See Griliches (1990) for more details on this story. 
sis of "exhaustion of inventive opportunities" as a potential explanation for the productivity slowdown.

This hypothesis has been examined recently by various authors. There are basically two styles of analysis: one focuses directly on the link, if any, between R\&D and productivity growth (see e.g., Griliches, 1986a; Bronwyn Hall, 1993; Scherer, 1993), while the other uses patents as indicators of the output of the R\&D effort and looks at what has happened to the "knowledgeproduction function" (see e.g., Griliches, 1990; Ricardo Caballero and Adam Jaffe, 1993; Robert Evenson, 1993; Samuel Kortum, 1993). The bridge that is missing between these two approaches would examine the units in which patents affect productivity growth and ask whether they have stayed constant over time. Without such constancy, no clear interpretation is possible.

\subsection{Productivity Growth and the Role of $R \& D$}

In parallel to the aggregate "residual" literature, a more micro-oriented approach had developed. It took the study of technical change, diffusion, and the role of formal $R \& D$ as its main challenge, with the hope of bringing more of it within the realm of economic analysis, helping thereby also to explain some of this residual away. Using modern language, one can interpret Edwin Mansfield's and my own early work on diffusion and on the role of R\&D in agriculture and manufacturing as trying to endogenize as much of technical change as was possible (Griliches, 1957, 1958, 1964; Mansfield, 1961, 1965). Other important contributors to this literature were Richard Nelson, Scherer, Jacob Schmookler, and Nestor Terleckyj. By expanding the notion of capital to include also R\&D capital and estimating its effects, this literature documented the contribution of public and private investments in $R \& D$ and their spillovers to the growth of productivity. ${ }^{4}$ But the magnitude of the estimated effects was modest, not enough to account for the bulk of the observed residual or the fluctuations in it (Griliches, 1988). The experience here was similar to other attempts to account for the residual, such as using "embodiment" theories to magnify the potential effects of capital accumulation (Denison, 1962; Nelson, 1962) or looking for increasing returns to scale (Griliches and Vidar Ringstad, 1971). These various effects are real and nonnegligible, but not large enough.

There is one other way of trying to make something more out of the $R \& D$ story: the possibility that the productivity impact of R\&D has declined over time-that the coefficients have changed. This hypothesis has been investigated repeatedly by a number of researchers with mixed results. Studies that used data through the 1970s and early 1980s found no decline in the relevant coefficients. More recent studies that analyze data through the late 1980 s report more mixed results, varying strongly with how the computer industry and

4. This literature has been surveyed in Griliches (1979, 1991), Jacques Mairesse and Mohamed Sassenou (1991), Wallace Huffman and Evenson (1993), and M. I. Nadiri (1993). 
Table 14.1

Industry TFP Growth Regressions: Coefficients of the R\&D-Sales

Ratio by Period, Three-Digit SIC Level ( $N=143$ or 142)

\begin{tabular}{llll}
\hline Row & \multicolumn{1}{c}{ Period } & With computers & Without computers \\
\hline 1 & $1958-1973$ & $0.332(0.066)$ & $0.317(0.066)$ \\
2 & $1973-1989$ & $0.357(0.072)$ & $0.134(0.059)$ \\
3a & $1978-1989$ & $0.300(0.073)$ & $0.115(0.062)$ \\
3b & $1978-1989$ "revised" & $0.461(0.070)$ & $0.348(0.070)$ \\
\hline
\end{tabular}

Notes: The equations include also dlog(energy/capital) as an additional utilization variable. Standard errors are shown in parentheses. The ratio of company-financed R\&D to total sales in 1974 is from Scherer (1984) for row 1; this ratio is updated for 1984 from National Science Foundation (1992) for rows 2 and 3. Row 3b shows total-factor-productivity growth revised downward for computers and upward for electronic components and drugs (computers = SIC 357).

its deflator are handled in the analysis. ${ }^{5}$ At the same time, the stock market's valuation of $R \& D$ fell significantly, in terms of both ex post returns to $R \& D$ in the 1980s (Michael Jensen, 1993) and the market's view of current R\&D investments (Bronwyn Hall and Robert Hall, 1993; B. Hall, 1993).

My own recent foray into this type of analysis of industry data at the threedigit SIC level is summarized in Table 14.1. ${ }^{6}$ It reports estimates from regressions of growth rates in total factor productivity (TFP) on the rate of investment in $R \& D$ (the R\&D-sales ratio), where the estimated coefficient can be interpreted as the excess gross rate of return to $R \& D$ (Griliches, 1979). The earlier 1958-1973 period yields an estimate on the order of 0.33 , while the estimate for the later 1973-1989 period even rises a bit, to 0.36. So far, so good! But when one excludes the outlier computer industry (see Fig. 14.2) the estimated coefficient falls from 0.36 to 0.13 for $1973-1989$ and even lower for 19781989. Only one observation out of 143 does this! ${ }^{7}$

These results raise a major data conundrum: is it right to treat the computer industry as an outlier and exclude it from such calculations just because the

5. As reported in Griliches (1986a), I found no significant decline in the relevant coefficients through the mid-1970s. Frank Lichtenberg and Donald Siegel (1991) replicated and extended this work to the early $1980 \mathrm{~s}$ and found increases in the relevant coefficients through 1985 . B. Hall (1993) updated and extended the Griliches and Mairesse (1984) study of publicly traded U.S. manufacturing firms to the end of the 1980s and found that the R\&D coefficients came close to disappearing in the 1970 s and early 1980 s but recovered in the late 1980 s to about half or more of their original size. Her result is very sensitive, however, to the particular deflators used in constructing the output measure. When separate industry-level deflators are used, including the newly revised deflator for the output of the computer industry, there is no evidence of a decline in the "potency" of R\&D at all; the estimated coefficients rise rather than fall. See also Englander et al. (1988), Pari Patel and Luc Soete (1988), Sveikauskas (1990), and Scherer (1993).

6. The total-factor-productivity numbers come from the National Bureau of Economic Research data base (Wayne Gray, 1992). The R\&D numbers come from Scherer (1984), updated to 1984 using 2.5-digit-level information from National Science Foundation (1992).

7. Updating the Griliches and Lichtenberg (1984) results for 28 2.5-digit SIC industries and using a possibly more appropriate R\&D-by-product-field measure yields essentially similar results, as does a parallel computation at the more aggregated two-digit SIC level using unpublished Bureau of Labor Statistics data on total (five-factor) productivity. 


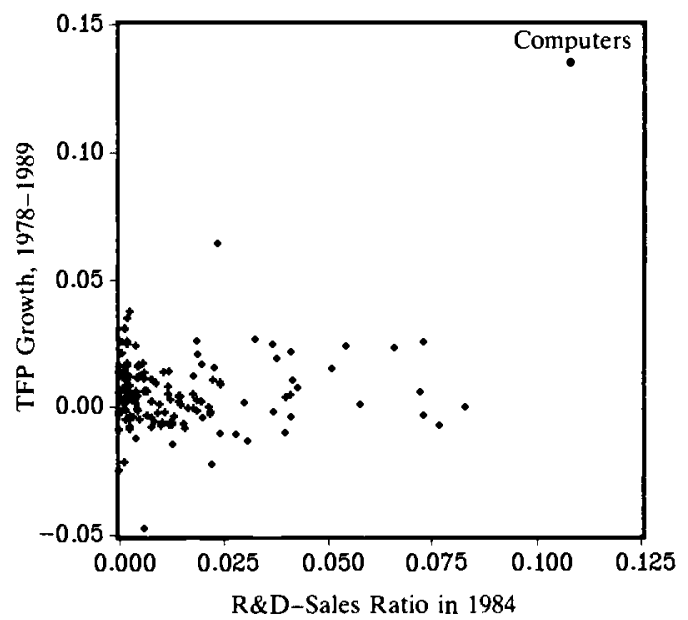

Fig. 14.2 Total-factor-productivity growth (per annum) and research intensity in U.S. manufacturing, three-digit SIC level, 1978-1989

productivity measure may be better there? It is quite possible that if other technologically advanced industries (such as instruments, communications equipment, and pharmaceuticals) had their price indexes adjusted in a similar fashion, Figure 14.2 would look much better, with the computer industry not being as much of an outlier and with the whole period showing much higher (social) returns to $R \& D$. That this is indeed the case can be seen in Figure 14.3, where only three such adjustments are made, but before I discuss it, I need to digress briefly and remind you about the developments in computer price measurement.

Quality change is the bane of price and output measurement. Until 1986, computer prices were treated as unchanged in the national income accounts. It took 25 years for the recommendations of the Stigler committee (Griliches, 1961; National Bureau of Economic Research, 1961) to have a noticeable effect on official practice, but when they did, they did it with a bang! In 1986 the Bureau of Economic Analysis (BEA) introduced a new computer price index, based on hedonic regression methods, into the national accounts and revised them back to 1972 (Rosanne Cole et al., 1986). ${ }^{8}$ This index was falling by about 15 percent per year or more (as compared to the assumed value of zero before), and that had several major implications, including the fact that it made the apparent recovery in manufacturing productivity in the 1980s much stronger, about one-third of the total coming from the introduction of this price index alone (Gordon, 1993b).

There was nothing wrong with the price index itself. It was, indeed, a major

8. For historical background on these developments see Jack Triplett (1989) and Ernst Berndt (1991 Ch. 4). 
advance, and the BEA should be congratulated for making it, but the way it was introduced created some problems. First, it was a unique adjustment. No other high-tech product had received parallel treatment, and thus it stuck out like a sore thumb. This had the unfortunate consequence that the productivity growth in the computer industry itself was seriously overestimated, because some of its major inputs, such as semiconductors, were not similarly deflated. Second, it was introduced into a framework with fixed weights, wreaking havoc on it. Using fixed 1982 weights and a sharply falling price index implied the absence of a "real" computer industry in the early 1970 s and a very rapid growth in its importance, leading to a more than doubling of the share of machinery in total manufacturing output by the late 1980s. This last problem has largely been solved recently with the introduction of "benchmark-weighted" estimates of gross domestic product (GDP) and the moving away from fixedweights national income accounting (Allan Young, 1992). But the first problem, the uniqueness of this adjustment in the face of similar, though perhaps not as extreme, problems elsewhere remains to haunt us.

What I have done in Figure 14.3 (and in row $3 \mathrm{~b}$ of Table 14.1) is to adjust the estimated TFP growth in the computer industry downward by deflating materials purchases in this industry, which to a significant extent consist of purchases of other computer components and semiconductors, by the same output price index. I have also substituted a similar price index in the semiconductors (electronic components) industry and also adjusted the growth of TFP in the pharmaceuticals industry upward to reflect the exclusion of price declines due to the introduction of generics in the current measurement procedures. (I shall come back to discuss this last adjustment later on.) So adjusted,

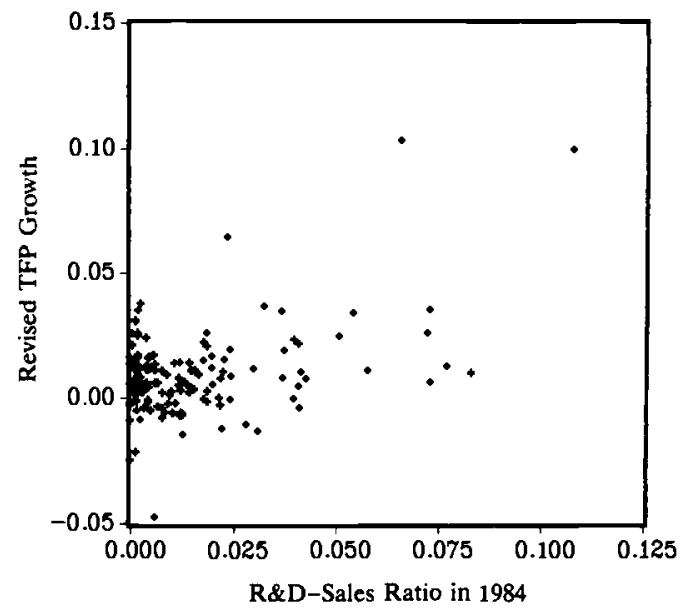

Fig. 14.3 Revised total-factor-productivity growth (per annum), U.S. threedigit manufacturing industries, 1978-1989

Note: Computers adjusted downward; electronic components and drugs adjusted upward. 
Figure 14.3 does not look all that bad, and row $3 b$ in Table 14.1 indicates no decline in the R\&D coefficient even without the computer industry.

What is one to make of these conflicting stories? It seems that the observed decline in the R\&D coefficients did not begin seriously until the latter half of the 1970s, with the second oil-price shock and the rise in the dollar exchange rate. The abruptness of the decline argues against a "supply-side" explanation in terms of exhaustion of inventive opportunities. It is more likely that the peculiar aggregate shocks of that time went against $R \& D$-intensive industries: first, because they hit energy-intensive industries such as chemicals and petroleum refining more severely; and second, because the subsequent rise in value of the dollar and the expansion in imports that followed hit some of the more high-tech R\&D-intensive industries even harder, leading to declines in "competitiveness," losses of rents, and the appearance of excess capacity. The subsequent rise in the $\mathrm{R} \& \mathrm{D}$ coefficients (if it did in fact occur), the rise in corporate R\&D investments through most of the 1980s, and the rise in patenting in the late 1980s (as we shall see), all argue against interpreting these coefficient movements as reflecting "real" declines in the once and future "potency" of $\mathrm{R} \& \mathrm{D}$. What did happen, though, was a sharp widening of the differential between social and private returns to $R \& D$. The internationalization of $R \& D$, the rise in the technical and entrepreneurial skills of our competitors, and the sharp rise in the dollar exchange rate in the mid-1980s, all combined to erode, rather rapidly, the rents accruing to the earlier accumulated $R \& D$ capital and to the technical-expertise positions of many of our enterprises. This rise in the rate of private obsolescence and the fall in the "appropriability" of R\&D led to sharp declines in both profitability and real product prices. The latter, if they were actually reflected in the appropriate price indexes, would show up as an increase in productivity, rather than a decline.

Before accepting this inconclusive verdict, one still has to face the evidence of declining patent-to-R\&D ratios. Figure 14.4 plots domestic patent applications divided by total company-financed R\&D expenditures in U.S. industry (in 1972 dollars) and by the total number of scientists and engineers in industry. Looking at the right half of this plot (the last couple of decades) we see a more or less continuous decline with a small, but possibly significant, turnaround in the late 1980s. Similar trends can be seen also in other countries, even in Japan (Evenson, 1991). But before one takes this as an indicator of our recent problems, one should glance also at the left side of this figure, which goes back to the early 1920s. How long has this been going on? This ratio keeps falling, both through good times (while productivity growth rates were rising) and bad times. If this was not a cause for worry earlier, why should one worry about it now?

9. Actually quite a few people worried about it then also: see Griliches (1990) for more detail and W. Fellner (1970), who worried about the rising real cost of R\&D as an indicator of diminishing returns. 


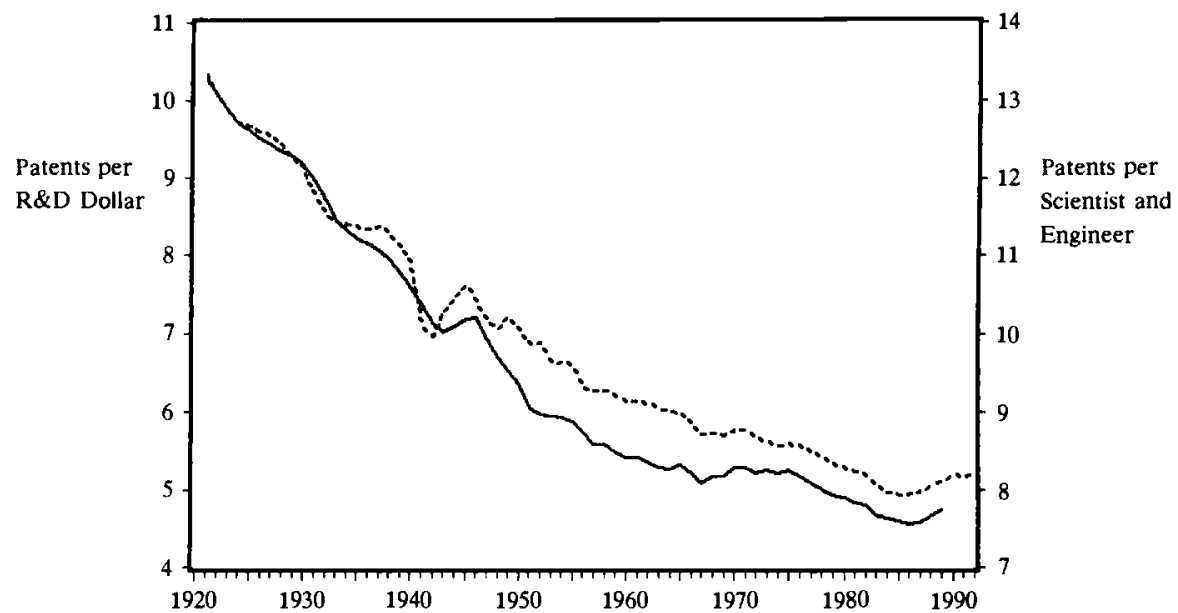

Fig. 14.4 Domestic patent applications per company-financed R\&D in industry (dashed line; in 1972 dollars) and per scientist and engineer (solid line), log scale

\subsection{Patents: A Shrinking Yardstick?}

To decide whether we should be worried by what is happening with the patent numbers we need to know what they measure. Since I have discussed this at some length elsewhere (Griliches, 1990), I will make only two points here. First, the interpretation of Figure 14.4 need not be pessimistic. Its message may not be what meets the eye. And, second, the meaning of both the numerator and the denominators of the ratios plotted in Figure 14.4 may have changed significantly over time.

If patents can be taken as indicators of invention, and if the value of an invention is proportional to the size of its market (or economy), then the fact that their total numbers remained roughly constant over long time periods is consistent with nondeclining growth rates of output and overall productivity. ${ }^{10}$ If inventions are "produced" by a combination of current $R \& D$ and the existing state of knowledge (incorporating the accumulated effects of science and spillovers from the previous research activities of others), and if R\&D is invested approximately "optimally," then under reasonable assumptions, a rise (or fall) in the underlying knowledge stock will affect them both in parallel fashion and will leave their ratio unchanged. ${ }^{11}$ There will be, therefore, no evidence in this

10. This follows from the nonrival nature of inventions (see Kenneth Arrow, 1962; Paul Romer, 1990).

11. Assume an aggregate inventions "production function" of the form $N=R^{\gamma} Z$, where $R$ is a measure of current $R \& D$ inputs and $Z$ represents all other shifters of this function: the accumulation of one's own past $R \& D$ successes and also spillovers from the research efforts of others. Then, $\gamma<1$ implies short-run diminishing returns to current $\mathrm{R} \& \mathrm{D}$, a "fishing-out" phenomenon given the current "state of the art" $Z$. To the extent that endogenous (and exogenous) forces "recharge" 
ratio on the underlying state of the "stock of knowledge." Moreover, it will be declining with growth in the size of the market, since a rise in the value of inventions will push $\mathrm{R} \& \mathrm{D}$ up until present costs equal again the present value of future (private) returns.

The rate of growth of domestic patents was close to zero during the last three decades. That by itself should not be worrisome. If their average value had been growing at the same rate as the economy as a whole, there would be no reason for us to worry about it. But there were long periods when the actual numbers were worse than that. During 1965-1985 the number of domestic patent applications declined by -0.6 percent per year while company-financed $\mathrm{R} \& \mathrm{D}$ expenditures were growing by 4.8 percent per year, in constant prices. But a negative growth rate in the number of inventions and a positive one in $\mathrm{R} \& \mathrm{D}$ are inconsistent with an unchanging inventions production function, unless the overall pool of available knowledge is declining, or more likely, unless the relationship between inventions and the number of patents applied for has been changing.

The suspicion that the relationship between the number of patents and the number of inventions (weighted by their relative economic importance) has been changing is not new. Schmookler (1966) stops most of his analysis with pre-World War II data, believing that the meaning of the patent statistics changed at that time. What needs to be reconciled in the data is the sharp contrast between the rapidly growing R\&D series during 1953-1968 (and earlier) and the essentially flat patent series. There are a number of not mutually exclusive possibilities here:

(i) The fast-growing R\&D expenditures, fueled by the new global opportunities that opened up in the post-World War II period, were being invested in the face of rapidly diminishing returns.

(ii) Some of the observed growth in $R \& D$ could be spurious, the result of reclassification of informal technological activities into formal $R \& D$ under the pressure of tax accountants, public-relations experts, and R\&D tax credits.

(iii) The rise of formal $\mathrm{R} \& \mathrm{D}$-based invention crowded out smaller, less valuable individual-inventor-based patents, while the rise in the cost of patenting (in terms of the time costs of dealing with the patent system) and the more recent sharp rise in fees may have selected out a large number of

the pool (in Evenson's [1991] terminology) and change $Z$ as the result of the direct and indirect additions to the overall stock of knowledge, there need not be diminishing returns to $R$ in the long run. If $R$ is chosen so as to equate the value of its marginal product, $V(\gamma N / R)$, to the marginal real cost of $R, C$, and if $V$ is the expected present value of an invention, one can rewrite the first-order condition as $N / R=C / \gamma V$, which yields the major conclusion that the ratio of inventions per unit of R\&D is independent of the state of general knowledge $Z$. Moreover, $N / R$ will be declining in $V$, the size of the market. For a more detailed elaboration of such models see the "quality-ladders" approach of Gene Grossman and Elhanan Helpman (1991), Caballero and Jaffe (1993), and Kortum (1993). 
potentially low-valued patents. Given the evidence that the value distribution of inventions and patents is extremely skewed, with only a small fraction having a high present value, such a crowding out could raise average values significantly, though the required rate is rather on the high side..$^{12}$

It is also likely that the threshold for what is patentable has risen, given the large influx of foreign patent applications into the U.S. system all impinging on a relatively slow-growing and budget-constrained patent office..$^{13}$ On the other hand, the legal status of patents in the United States has improved significantly with the creation of a special patents court, driving up the expected private value of a patent. Given the presence of so many opposing forces, there is no compelling need to rely on the exhaustion-of-inventive-opportunities hypothesis, especially since patents-to-R\&D ratios were falling much more drastically during the "good times" of the past than recently. ${ }^{14}$ Moreover, if we do take these numbers seriously, then good news is just around the corner: domestic patent applications have risen sharply in the last five years (see Fig. 14.5), implying a potential resurgence in the rate of technological change. This leaves us, however, more or less where we started, with the productivity slowdown largely unexplained.

\subsection{Why Is the Glass Half-Empty?}

Economists have not been very successful in explaining what has happened to the economy during the last two decades, nor have they been able to agree on what should be done about it. I will argue that data and measurement difficulties may in fact be a major source of this failure. This point will be made not to provide us with an alibi, but rather to temper the pretentiousness of some of our pronouncements and to urge us toward the more mundane tasks of observation and measurement.

12. There is scattered evidence on the rising "quality" of patents from patent renewal data (see Mark Schankerman and Ariel Pakes, 1986; Pakes and Margaret Simpson, 1989) and from the rising number of claims per patent (see X. Tong and J. D. Frame, 1992). The latter, for example, rose at about 2.5 percent per year between 1970 and 1990. That is about right for this period but far too low for the 6+ percent earlier. On the other hand, Caballero and Jaffe (1993), using citation data, find that the average "size" of a patent did not grow during the last 20 years.

13. There is some evidence that such crowding-out may have occurred. Between 1966-1969 and 1981-1985 the "yield ratio" for domestic patent applications in terms of grants received fell by about 15 percent (from 0.68 to 0.58 ) before recovering somewhat in the late $1980 \mathrm{~s}$ (to 0.62 ). See Griliches (1990) for a survey of these issues and citations of the relevant literature.

14. A similar story is also told by other scattered invention "output" indicators. In their study of innovations in the chemical, textile, and machinery-tools industries, Baily and Chakrabarti (1988) found a decline in the number of innovations in the 1970 s in two out of these three industries, and some recovery thereafter. Similar patterns were observed in a study of British industrial innovations (see the figure in Gerhard Mensch et al. [1991]). In both cases the timing is not right for an explanation of the slowdown in the 1970s. The impact on productivity is too fast. Rather, it is likely to reflect the impact of the slowdown in the growth of aggregate demand and the recessions of the 1970s. In both cases there is an upturn in the 1980s. 


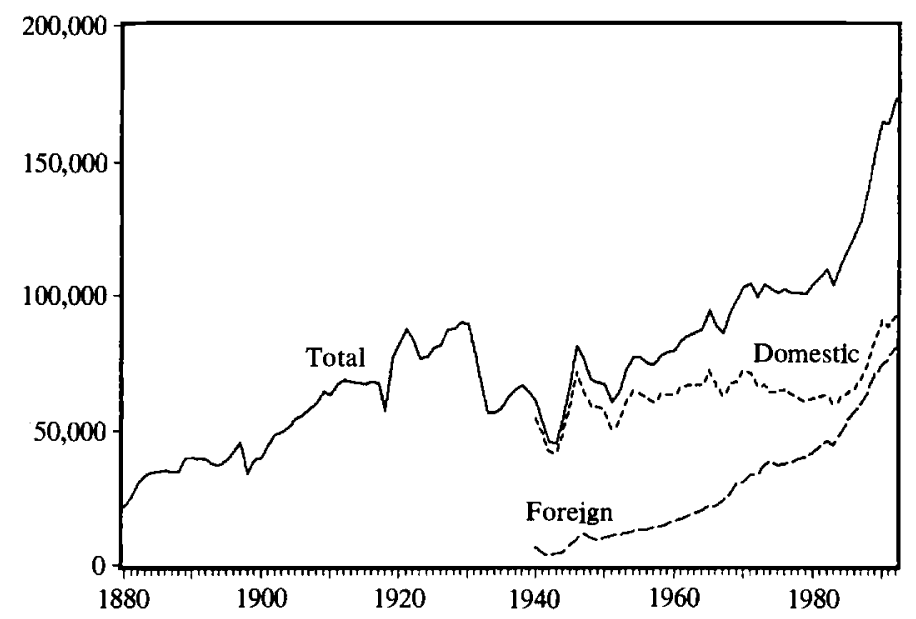

Fig. 14.5 Patent applications in the United States, 1880-1992

Why don't we know more after all these years? Our data have always been less than perfect. What is it about the recent situation that has made matters worse?

The brief answer is that the economy has changed and that our datacollection efforts have not kept pace with it. "Real" national income accounts were designed in an earlier era, when the economy was simpler and had a large agricultural sector and a growing manufacturing sector. Even then, a number of compromises had to be made to get measurement off the ground. In large sectors of the economy, such as construction and most of the services, government, and other public institutions, there were no real output measures or relevant price deflators. Imagine a "degrees of measurability" scale, with wheat production at one end and lawyer services at the other. One can draw a rough dividing line on this scale between what I shall call "reasonably measurable" sectors and the rest, where the situation is not much better today than it was at the beginning of the national income accounts. Table 14.2 shows the distribution of nominal GDP by major industrial sector. In the early post-World War II period, the situation was not all that bad: about half of the overall economy was "measurable" in this sense. By 1990, however, the fraction of the economy for which the productivity numbers are half reasonable had fallen to below one-third. Figure 14.6 tells the same story with employment numbers. Measurement problems have indeed become worse. Our ability to interpret changes in aggregate total factor productivity has declined, and major portions of actual technical change have eluded our measurement framework entirely. ${ }^{15}$

15. An argument could be made that this story would not be so bleak if we had focused on consumption expenditures instead, since many of the offending industries produce largely intermediate products and services. But personal consumption expenditures account only for about 68 
Table 14.2

The Distribution of GNP by Major Industrial Sector, in Current Prices (Percentages)

\begin{tabular}{lrrrrr}
\hline Industry & 1947 & 1959 & 1969 & 1977 & 1990 \\
\hline Agriculture & 8.8 & 4.1 & 3.0 & 2.8 & 2.0 \\
Mining & 2.9 & 2.5 & 1.8 & 2.7 & 1.8 \\
Construction & 3.9 & 4.8 & 5.1 & 4.8 & 4.4 \\
Manufacturing & 28.1 & 28.6 & 26.9 & 23.6 & 18.4 \\
Transportation and utilities & 8.9 & 9.1 & 8.6 & 9.1 & 8.7 \\
Wholesale trade & 7.1 & 6.9 & 6.7 & 7.0 & 6.5 \\
Retail trade & 11.7 & 9.9 & 9.8 & 9.6 & 9.3 \\
Finance, insurance, and real estate & 10.1 & 13.8 & 14.2 & 14.4 & 17.7 \\
Other services & 8.6 & 9.7 & 11.5 & 13.0 & 18.9 \\
Government & 8.6 & 10.2 & 12.6 & 12.5 & 12.2 \\
"Measurable" sectors & 48.7 & 44.3 & 40.3 & 38.2 & 30.9 \\
\hline
\end{tabular}

Source: Tables 6.1 and 6.2 of the National Income and Products Accounts (1928-1982) and Survey of Current Business (May 1993).

Note: Numbers before 1977 are not strictly comparable, since the latest revision was carried back only to 1977.

${ }^{2}$ Agriculture, mining, manufacturing, and transportation and utilities.

An example of the consequences of this shift is what has come to be known as the "computer paradox." We have made major investments in computers and in other information-processing equipment. The share of "information" equipment in total producer investment in durable equipment, in current prices, has more than doubled, from about 17 percent in 1960 to 36 percent in 1992 . Computers alone went up from less than 1 percent to 11 percent of the total; and that does not allow for improvements in the quality of this equipment, which has been happening at a very fast rate-on the order of 15-30 percent per year (see Jack Triplett, 1989; Berndt and Griliches, 1993). Why has this not translated itself into visible productivity gains? The major answer to this puzzle is very simple: over three-quarters of this investment has gone into our "unmeasurable" sectors (see Table 14.3), and thus its productivity effects, which are likely to be quite real, are largely invisible in the data.

That there were gains is not really in doubt. Just observing the changes in the way banks and airlines operate, and in the ways in which information is delivered to firms and consumers, would lead one to conclude that we are in the midst of a major technical revolution. Effective distances are declining rapidly in many parts of the world. The rise of ATM networks in banking has resulted in substantial though largely unmeasured time savings for consumers.

percent of GDP, while services represent 56 percent of personal consumption. Thus, it is unlikely that looking at consumption data in more detail would change the tenor of my remarks much. A cursory look at Personal Consumption Expenditures (Bureau of Economic Analysis, 1990) yields a rough estimate of 47 percent of total consumption expenditures not easily measurable in real terms. The two largest difficult items consist of hard-to-measure services in the medical, insurance, legal, entertainment, and education areas ( 23 percent) and housing-related services ( 21 percent). 


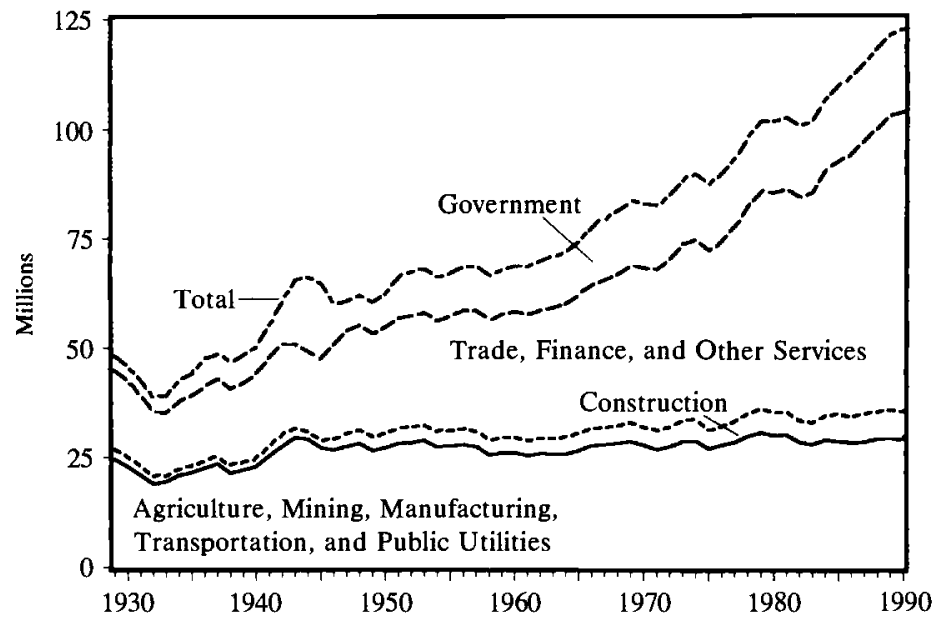

Fig. 14.6 Persons engaged in production by industry, United States, 1929-1990

Table 14.3

Investment in Computers (OCAM) in the U.S. Economy (Percentage of Total)

\begin{tabular}{lrrr}
\hline Industry & 1979 & 1989 & 1992 \\
\hline Agriculture & 0.1 & 0.1 & 0.1 \\
Mining & 2.4 & 1.1 & 0.9 \\
Construction & 0.1 & 0.3 & 0.2 \\
Manufacturing & 29.4 & 20.3 & 20.0 \\
Transportation & 1.3 & 2.0 & 1.0 \\
Communication & 1.5 & 1.4 & 1.5 \\
Utilities & 1.2 & 2.8 & 3.7 \\
Trade & 19.9 & 16.3 & 20.0 \\
Finance, insurance, and real estate (F.I.R.E.) & 32.5 & 38.7 & 37.8 \\
Other services & 11.6 & 17.0 & 13.9 \\
"Unmeasurable" sectors & & & \\
Plus consumer and government purchases as & 64.1 & 72.3 & 71.9 \\
percentage of all computer (OCAM) purchases & 67.7 & 77.6 & 77.0 \\
\hline
\end{tabular}

Source: Unpublished BEA tabulations.

Notes: OCAM = office, computing, and accounting machinery.

${ }^{a}$ Construction, trade, FI.R.E., and other services.

It is less clear, however, whether the large expansion of the securities industry has been associated with a similar productivity increase or was primarily a response to a real decline in the cost of rent-seeking induced by the falling price of information processing (see Timothy Bresnahan et al., 1992).

There is also some scattered evidence for the positive contribution of computers in manufacturing, but given the needle-in-the haystack aspect of this problem, it is not particularly strong (see e.g., Alan Krueger, 1993; Donald 
Siegel and Griliches, 1992; Erik Brynjolfsson and Lorin Hitt, 1993; Igal Hendel, 1993). Some of the gains from computers have been reflected in higher wages of their operators and in the more general rise in the returns to education and "skill" (Chinhui Juhn et al., 1993). More generally, we may be just at the beginning of the computer era, early in its diffusion and learning stages, with most of the productivity contributions still to come, as we learn how to use computers more effectively and integrate them more efficiently into the existing production structures (Paul David, 1991).

Similar arguments, can be (and have been) made about the difficulties in measuring the contribution of $R \& D$ to productivity growth (see Griliches, 1979). From one-third to over half of all industrial R\&D is "sold" to the government, either in the form of research contracts and prototypes or indirectly in the form of weapons and space equipment, and its direct productivity effects do not show up in the data at all. Private R\&D investment is also likely to have followed the economy and shifted its targets toward the faster-growing sectors, with more invention and technical change occurring exactly where we have more trouble in measuring them.

Not only has the economy shifted into uncharted waters, but even in the "measurable" sectors accelerating rates of change have destroyed the basis for some of the older compromises. Currently, new goods are introduced into the various official price indexes rather slowly. While attempts are being made to reduce the revision cycle in the producer price index from five to two years for some of the more high-tech goods, this may still not be fast enough. In the personal-computers market, for example, the life of a model has recently fallen to a year or less (Berndt et al., 1995).

Dealing with the quality-change problem by treating every version of a product sold to a different type of customer as a separate commodity, as is currently the predominant official practice, creates its own problems. By linking out the decline in prices experienced by consumers in their shift to supermarkets, discount stores, and mail-order purchases, it underestimates significantly not only the output of services, but also the output of some of the more "standard" manufacturing industries (Marshall Reinsdorf, 1993). A prime example of that is the treatment of generics in the pharmaceutical price indexes. The stylized facts are as follows:

(i) Generics are introduced at roughly half the price of the original brand.

(ii) The brand price, however, does not decline (it sometimes even goes up), with the ex-monopolist depreciating optimally her original position and with generics gaining between half and three-quarters of the market for the particular drug.

(iii) But because generic versions are treated as separate commodities, in spite of what the FDA says, the price index does not fall, and since the value of shipments declines as the market shifts to generics (and to hospital and 
HMO formularies), so does measured "output" in this industry and the associated productivity measures (Griliches and Iain Cockburn, 1994).

This might explain the rather strange fact that during the last decade pharmaceuticals, an industry with one of the highest R\&D-sales ratios, had a rather dismal productivity-growth performance. This was the period with an increasing penetration of generics, which should have reduced measured prices in this industry but did not.

The measurement environment has deteriorated also in other ways. There is less willingness on the part of firms and consumers to respond to detailed questions, and our government has done little to emphasize the importance of good economic data to its own functioning or to the overall understanding of our economy. The consequence of such deterioration can be illustrated by the uncertainty about the level of industrial investment in basic research, an investment which many think is crucial to our long-run economic performance (Griliches, 1986a). Because the question that asks about the allocation of total R\&D expenditures by the "character of work" is not mandatory and is also not an easy one to answer, less than half of all the firms surveyed in 1988 answered it. As a result of such nonresponse, the best that can be done is to produce a "reasonable" range of estimates, based on alternative imputation algorithms, from $\$ 2.5$ to $\$ 8.2$ billion (and a "central" guess of $\$ 3.9$ billion), which leaves us really in the dark as to what has happened to such investments recently (Eileen I. Collins, 1990).

\subsection{Data Woes}

Why are the data not better? The facts themselves are not in dispute. Every decade or so a prestigious commission or committee produces a report describing in detail various data difficulties and lacunae: the Stigler committee report on government price statistics (National Bureau of Economic Research, 1961) is still a living document, as are the related Ruggles report (Richard Ruggles, 1977), the Rees productivity report (National Academy of Sciences, 1979), the Bonnen report (J. T. Bonnen, 1981), the Creamer GNP improvement report (D. Creamer, 1977), the recent OTA report (Office of Technology Assessment, 1989), and many others. But life goes on, and change in this area is very slow. Why? I don't really have good answers to this question, and the topic itself is much larger than can be handled in this address, but at least three observations come to mind:

(i) The measurement problems are really hard.

(ii) Economists have little clout in Washington, especially as far as datacollection activities are concerned. Moreover, the governmental agencies in these areas are balkanized and underfunded. 
(iii) We ourselves do not put enough emphasis on the value of data and data collection in our training of graduate students and in the reward structure of our profession. It is the preparation skill of the econometric chef that catches the professional eye, not the quality of the raw materials in the meal, or the effort that went into procuring them (Griliches, 1986b).

In many cases the desired data are unavailable because their measurement is really difficult. After decades of discussion we are not even close to a professional agreement on how to define and measure the output of banking, insurance, or the stock market (see Griliches, 1992). Similar difficulties arise in conceptualizing the output of health services, lawyers, and other consultants, or the capital stock of R\&D. While the tasks are difficult, progress has been made on such topics. The work of Jorgenson and Barbara Fraumeni (1992) on the measurement of educational output is an example both of what can be done and of the difficulties that still remain. But it is not reasonable for us to expect the government to produce statistics in areas where the concepts are mushy and where there is little professional agreement on what is to be measured and how. Much more could be done, however, in an exploratory and research mode. ${ }^{16}$ Unfortunately, the various statistical agencies have been both starved for funds and badly led, with the existing bureaucratic structure downplaying the research components of their enterprise when not being outright hostile to them, research being cut first when a budget crunch happens (Triplett, 1991).

Our current statistical structure is badly split, there is no central direction, and the funding is heavily politicized. How else can one explain that the national income accounts and the BEA as a whole receive only one-third, and health and education statistics each less than one-half of the funds allocated to agricultural statistics? ${ }^{17}$ How does one explain the failure of the most recent attempt at getting more money for economic statistics, the late "Boskin initiative"? Central economic statistics do not have a clear constituency that lobbies on their behalf. Recent governments seem not to care enough, or to have enough energy to fight for something that has a more distant horizon than the next election. One hopes for some improvement in this situation from the current administration. It has people who know better in reasonably important positions. Still, with the main focus on the daily crisis and the continuing bud-

16. I refrain from offering a detailed list of my own favorite data improvements; but a census of real wealth (i.e., a survey of structure, equipment, and other resources and their utilizationnot just what is on the books, but what is actually out there in the field) would be high on my list. I would also like to see a survey of patent owners on the use and potential value of their property rights.

17. I am not arguing that too much is currently being spent on agricultural statistics. That would require a substantive analysis, which has not been done. I am saying, however, that the other areas of federal statistics could use both more funding and a redirection of existing funding. We are also currently spending far more on monthly employment and average hourly earnings data than we spend to collect all of the other inputs and outputs annually. With Congressional prodding, we spend much more on local-markets data than on national-level data. 
get battles with Congress, I am not all that optimistic. But if we want progress in this area, if we care, we need to make our opinions heard. We need to convince Congress (and ourselves) that the requests for additional funding of the statistical infrastructure are justified as investments in general knowledge and more informed policy formation; that they are not just self-serving, intended to allow us to publish more articles or run thousands more regressions; that it is indeed important to know what is happening and to understand where we might be going or drifting. ${ }^{18}$

We need also to make observation, data collection, and data analysis a more central component of our graduate teaching. How can we expect our community to fight for the budgets of the BEA, BLS, or Census, if the average student doesn't really know how the data that they use are manufactured or what the national accounts are made of ${ }^{19}$ We also need to teach them to go out and collect their own data on interesting aspects of the economy and to rely less on "given" data from distant agencies..$^{20}$ There are encouraging signs that some of this is happening, especially in the micro area. One is much more cheered by work such as that of Robert Fogel (1986) on heights and nutrition, Alan Krueger and Orley Ashenfelter (1994) on twins, Richard Levin et al. (1987) on the appropriability of technology, Rebecca Henderson and Cockburn on pharmaceutical R\&D, Richard Freeman and Harry Holzer (1986) on innercity youths, Schankerman and Pakes (1986) on patent renewal data, Manuel Trajtenberg (1990a) on CT scanners, and Trajtenberg (1990b) and Adam Jaffe et al. (1993) on patent citations, where researchers go out, collect, and create new data sets, than by the 20,000th regression on the Robert Summers and Alan Heston (1991) data set, illuminating as it may be. But unless we transmit this message to our students, we will not be able to convince others that this is a cause worth supporting.

\subsection{Expanding the Framework}

Is there something possibly wrong with the way we ask the productivity question, with the analytical framework into which we force the available data? I think so. I would focus on the treatment of disequilibria and the measurement of knowledge and other externalities. The current measurement framework

18. One should probably worry also about the overall level of support for economic research. As a percentage of total academic research funding, it fell from 1.5 percent in 1979 to 1.2 percent in 1990. While the number of economists doing academic research was rising at 5.5 percent per year, funds per researcher were falling in real terms at -2.3 percent per year, and the Federal share in these funds was also dropping from 48 percent to only 27 percent (in 1989). At the same time, real funds per researcher in the academy as a whole were rising at 0.4 percent per year (National Science Board, 1991). What is it that we have been doing wrong?

19. The recent shift toward a "three essays" $\mathrm{Ph} . \mathrm{D}$. thesis is also not conducive to a serious involvement with data creation.

20. Unfortunately, the usage is apt. Data already means "given" rather than collected or observed. 
proceeds as if all investment and employment decisions are made at known and common factor and product prices, throwing all of the heterogeneity and uncertainty - the surprises and the disappointments-into the residual category. An alternative view would see measured productivity growth as a summation of above- (and below-) average returns to various current investment decisions and capital gains (or losses) on existing physical- and human-capital stocks. ${ }^{21}$ The appearance of such investment opportunities is the essence of growth and change. They are largely disequilibrium phenomena, resulting in a lurching from one "steady state" to another rather than something smooth and exponential. The presence of locally increasing returns, network externalities, asymmetric information, and heterogeneous expectations, the appearance of new products and technologies, and the changes in the political and regulatory environments are all sources of such "excess" returns, while the ex post fixity of much of the investment in both physical and human capital causes capital gains and losses and unanticipated "obsolescence" in the various stocks. We will have to figure out how to take the residual apart along such lines to make more progress in understanding its proximate sources.

Our theories tend to assume that we are, indeed, at the frontier and that we can only either move along it or try to shift it, the latter being a difficult and chancy business. In fact we may be far from our existing "frontiers." Harvey Leibenstein's (1966) ideas about X-efficiency, or more correctly Xinefficiency, did not get much of a sympathetic ear from us. They were inconsistent with notions of equilibrium, the absence of unexploited profit opportunities, and the possibilities for economic arbitrage. But real economic growth is the consequence of both the appearance of such disequilibria and the devising of ways of closing them. How quickly they are eliminated depends on the strength of incentive systems within enterprises, and on their organizational quality. In spite of the large growth in the literature on organizations, we have not yet developed useful ways of quantifying their strengths and weaknesses. Nor are we close to having measures of such factors as the "work ethic" or aspects of the property-rights system which are likely to contribute much to the observed differences in productivity across nations.

The "new" growth theories have various externalities as their centerpiece (see Solow [1991] for a recent review). It is somewhat ironic that they have come to the fore just when growth started declining and notions of eternal exponential growth began to lose their luster. Knowledge externalities are obviously very important in the growth process, but they do not help us to explain what has happened in the last two decades. There is no reason to believe that they have declined over time. If anything, the communication and transportation advances should have expanded the availability of such externalities. ${ }^{22}$ But we have no good models for the measurement of such processes.

21. This is not a new idea. Versions of it appear in Harry Johnson (1964), Arnold Harberger (1990), and Theodore Schultz (1990) and presumably also elsewhere.

22. The story is similar for externalities from human-capital investments, another linchpin of the new growth theories, but I will not pursue it here. 
Knowledge is not like a stock of ore, sitting there waiting to be mined. It is an extremely heterogeneous assortment of information in continuous flux. Only a small part of it is of any use to someone at a particular point of time, and it takes effort and resources to access, retrieve, and adapt it to one's own use. Thus models of externalities must perforce be models of interaction between different actors in the economy. We have, however, very few convincing models of such interactions, and the identification problems are severe (see e.g., Charles Manski, 1993). Our measurement frameworks are not set up to record detailed origin and destination data for commodity flows, much less so for information flows. We do have now a new tool for studying some of this: citations to patents and the scientific literature (see e.g., Jaffe et al., 1993), but anyone currently active in the e-mail revolution and participating in the conferences and workshops circuit knows how small this tip is relative to the informal-communications iceberg itself.

\subsection{The Glass Half-Full?}

After a long detour I come back to the original question: why don't we know more about the sources of productivity growth and the causes for its recent slowdown? Why does it feel as if the glass is still half-empty? First note that in a trivial sense we are doing better: the residual is smaller. But that is the bad news, not the good. It is smaller not because we have succeeded in providing a substantively fuller explanation of output growth, but rather because measured output growth declined, leaving some of these explanations in the dust. But we are also doing better substantively. We know much more about the components of growth and where our measures are lacking. After decades of work and contributions by Denison, Jorgenson, Kendrick, and many others, the conceptual and measurement underpinnings of the growth accounts are in much better shape today. We now have extensive micro data on firms, their productivity, their R\&D expenditures, and other variables. We have more data on individual investments in education and training, and we also have more asset detail on capital formation. More international data are now available, with the OECD both collecting R\&D data and computing TFP numbers for many countries, and with Summers and Heston (1991) providing comparable real GNP numbers for many countries. Finally, we have much more computing power and better econometric techniques and frameworks for attacking many of the problems that arise in the analysis of such data. So what is still missing?

We are caught up in a mixture of unmeasurement, mismeasurement, and unrealistic expectations. The productivity situation is both better than we think and also worse. It is likely that there have been significant unmeasured productivity advances in many of the service sectors (Bresnahan, 1986; Baily and Gordon, 1988). Moreover, rising R\&D investment rates in the mid-1980s and the recent rise in the number of patent applications augur well for the future. Also, productivity growth rates are probably underestimated even in the "measurable" sectors because they are based on "book value" estimates of physical- 
and human-capital stocks and do not reflect the capital losses-the obsolescence that occurred, first as the result of the various energy-price shocks, and later as the result of increased international competition and the melting away of much of the previously existing monopoly rents to both types of capital. That is actually bad news. We are not as wealthy as we thought, but productivity growth, based on the lower remaining levels of input, is probably higher than we have measured it.

A cautionary remark needs to be added here: productivity growth contributes to the potential for welfare, but it is not the same thing. Welfare can move in the opposite direction if the resources released by productivity growth do not find adequate employment in other, economically valuable, activities (including leisure). Also the physical, economic, and political environments can change, both positively and negatively, overwhelming the productivity story. ${ }^{23}$ So even though I have been focusing on it here tonight, it is not the be-all of economic welfare. But as George Bernard Shaw used to say when he was accused of money-grubbing: "Yes, I know that money is not happiness, but it is a pretty good substitute."

Nevertheless, the issues I have been discussing here tonight are important. Much depends on whether the "truth" is closer to the upper ("measurable") line in Figure 14.1, or the lower one. The country's mood is affected by bad data and incorrect perceptions. Are we really not much better off than we were in the 1960s? Would we really like to exchange the commodity assortment we have today for that of yesteryear? Our health system, warts and all? The air pollution? The civil-rights situation? The fear of nuclear war? These are not just idle intellectual curiosities. They affect what we feel about ourselves and the future.

Returning to the topic of technical change, our expectations of what economics can deliver here may also be excessive. It is unlikely that we can have a fully "endogenous" theory of technical change. Yes, both the rate and direction of inventive activity are subject to economic influences and analysis. So also is the diffusion of innovations. But the outcome of inventive activity is not really predictable. True "innovation" is an innovation. If it were knowable in advance it would not be one, and the innovators would not be able to collect any rents. In that sense it is futile to expect that we could control it fully or predict it well..$^{24}$ Given the fundamental uncertainties entailed in the creative act, in invention, and in innovation, there is no reason to expect the fit of our models to be high or for the true residual to disappear. We should, however, be able to "explain" it better ex post even if we cannot predict it.

23. Between 1970 and 1989, average hours of work per worker went down by 7 percent, air pollution went down significantly, and the crime rate came close to doubling (Baily et al., 1993). Of course, these data are also problematic (see Scott Boggess and John Bound, 1993).

24. "The set of opportunities for innovation at any moment are determined by what the physical laws of the world really are and how much has already been learned and is therefore 'accidental' from the viewpoint of economics" (Arrow, 1969 p. 35). 
The metaphor of the glass half-empty is also misleading. As we fill it, the glass keeps growing. A major aspect of learning is that the unknown keeps expanding as we learn. This should be looked at positively. It is much better this way-especially for those of us who are engaged in research!

\section{References}

Abramovitz, Moses. "Resource and Output Trends in the U.S. since 1870." American Economic Review, May 1956 (Papers and Proceedings), 46(2), pp. 5-23.

Arrow, Kenneth J. "The Economic Implications of Learning by Doing." Review of Economic Studies, June 1962, 29(3), pp. 155-73.

- "Classificatory Notes on the Production and Transmission of Technological Knowledge." American Economic Review, May 1969 (Papers and Proceedings), 59(2), pp. 29-35.

Baily, Martin N.; Burtless, G. and Litan, R. E. Growth with equity: Economic policymaking for the next century. Washington, DC: Brookings Institution, 1993.

Baily, Martin N. and Chakrabarti, A. K. Innovation and the productivity crisis. Washington, DC: Brookings Institution, 1988.

Baily, Martin N. and Gordon, Robert J. "The Productivity Slowdown, Measurement Issues, and the Explosion of Computer Power." Brookings Papers on Economic Activity, 1988, (2), pp. 347-420.

Barton, Glen T. and Cooper, M. R. "Relation of Agricultural Production to Inputs." Review of Economics and Statistics, May 1948, 30(2), pp. 117-26.

Berndt, Ernst R. The practice of econometrics: Classic and contemporary. Reading, MA: Addison-Wesley, 1991.

Berndt, Ernst R. and Griliches, Zvi. "Price Indexes for Microcomputers: An Exploratory Study," in M. F. Foss, M. E. Manser, and A. H. Young, eds., Price measurements and their uses, NBER Studies in Income and Wealth, Vol. 57. Chicago: University of Chicago Press, 1993, pp. 63-93.

Berndt, Ernst R.; Griliches, Zvi and Rappaport, Neal. "Econometric Estimates of Price Indexes for Personal Computers in the 1990's." Journal of Econometrics, 1995, 68, pp. 243-68.

Boggess, Scott and Bound, John. "Did Criminal Activity Increase During the 1980s? Comparison Across Data Sources." National Bureau of Economic Research (Cambridge, MA), Working Paper No. 4431, 1993.

Bonnen, J. T. "Improving the Federal Statistical System: Issues and Options." Statistical Reporter, February 1981, pp. 133-221.

Bresnahan, Timothy F. "Measuring the Spillovers from Technical Advance." American Economic Review, September 1986, 76(4), pp. 741-55.

Bresnahan, Timothy F; Milgrom, P. and Paul, J. "The Real Output of the Stock Exchange," in Z. Griliches, ed., Output measurement in the service sectors, NBER Studies in Income and Wealth, Vol. 56. Chicago: University of Chicago Press, 1992, pp. 195-218.

Brynjolfsson, Erik and Hitt, Lorin. "Is Information Systems Spending Productive? New Evidence and New Results." Sloan School (Massachusetts Institutes of Technology) Working Paper No. 3571-93, 1993.

Bureau of Economic Analysis, U.S. Department of Commerce. The national income and product accounts of the United States, 1929-82. Washington, DC: U.S. Government Printing Office, 1986. 
Personal consumption expenditures, Methodology Paper Series MP-6. Washington, DC: U.S. Government Printing Office, 1990.

Caballero, Ricardo J. and Jaffe, Adam B. "How High Are the Giants' Shoulders?" in Olivier J. Blanchard and Stanley Fischer, eds., NBER macroeconomics annual, Cambridge, MA: MIT Press, 1993, pp. 15-74.

Cole, Rosanne; Chen, Y. C.; Barquin-Stolleman, J. A.; Dulberger, E.; Helvecian, N. and Hodge, J. H. "Quality Adjusted Price Indexes for Computer Processors and Selected Peripheral Equipment." Survey of Current Business, January 1986, 66(1), pp. 41-50.

Collins, Eileen I. "Estimating Basic and Applied Research and Development in Industry: A Preliminary Review of Survey Procedures," NSF 90-322. Washington, DC: National Science Foundation, 1990.

Creamer, D. Gross national product improvement project report. U.S. Department of Commerce, Office of Federal Statistical Policy and Standards. Washington, DC: U.S. Government Printing Office, 1977.

David, Paul A. "Computer and Dynamo: The Modern Productivity Paradox in a NotToo-Distant Mirror," in Technology and productivity. Paris: Organization for Economic Cooperation and Development, 1991, pp. 315-48.

Denison, Edward F. The sources of economic growth in the U.S. and the alternatives before us, Supplementary Paper No. 13. New York: Committee for Economic Development, 1962.

- Accounting for slower economic growth. Washington, DC: Brookings Institution, 1979.

Englander, A. S.; Evenson, R. E. and Hanazaki, M. "R\&D, Innovation, and the Total Factor Productivity Slowdown." OECD Economic Studies, Autumn 1988, (11), pp. 7-42.

Evenson, Robert E. "Technical Change in U.S. Agriculture," in R. R. Nelson, ed., Government and technical change: A cross industry analysis. New York: Pergamon, 1984, pp. 233-82.

- "Patent Data by Industry: Evidence for Invention Potential Exhaustion?" in Technology and productivity: The challenge for economic policy. Paris: Organization for Economic Cooperation and Development, 1991, pp. 233-48.

— . "Patents, R\&D, and Invention Potential: International Evidence." American Economic Review, May 1993 (Papers and Proceedings), 83(2), pp. 463-68.

Fabricant, Solomon. Economic progress and economic change. New York: National Bureau of Economic Research, 1954.

Fellner, W. "Trends in Activities Generating Technological Progress." American Economic Review, March 1970, 60(1), pp. 1-29.

Fogel, Robert. "Nutrition and the Decline in Mortality since 1700: Some Preliminary Findings," in Stanley Engerman and Robert Gallman, eds., Long-term factors in American economic growth, NBER Studies in Income and Wealth, Vol. 51. Chicago: University of Chicago Press, 1986, pp. 439-555.

Freeman, Richard and Holzer, Harry. The black youth employment crisis. Chicago: University of Chicago Press, 1986.

Gordon, Robert J. "Productivity, Wages, and Prices Inside and Outside of Manufacturing in the U.S., Japan, and Europe." European Economic Review, April 1987, 31(3), pp. 685-739.

- "Comment on Baily." Brookings Papers on Economic Activity, Microeconomics, 1993a, (2), pp. 131-52.

__ _ "American Economic Growth: One Big Wave." Unpublished manuscript, National Bureau of Economic Research, Cambridge, MA, 1993b.

Gray, Wayne. "Upgrading Productivity Data Through 1989." Mimeo, National Bureau of Economic Research, Cambridge, MA, 1992. 
Griliches, Zvi. "Hybrid Corn: An Exploration in the Economics of Technological Change." Econometrica, October 1957, 25(4), pp. 501-22.

_- "Research Cost and Social Returns: Hybrid Corn and Related Innovations." Journal of Political Economy, October 1958, 66(5), pp. 419-31.

- "Measuring Inputs in Agriculture: A Critical Survey." Journal of Farm Economics, December 1960, 42(5), pp. 1411-33.

- "Hedonic Price Indexes for Automobiles: An Econometric Analysis of Quality Change," in The price statistics of the federal government. Washington, DC: National Bureau of Research, 1961, pp. 173-96.

- "The Sources of Measured Productivity Growth: U.S. Agriculture, 19401960." Journal of Political Economy, August 1963a, 81(4), pp. 331-46.

- "Production Functions, Technical Change, and All That." Netherlands School of Economics, Econometric Institute Report No. 6328, 1963b.

—. "Research Expenditures, Education and the Aggregate Agricultural Production Function." American Economic Review, December 1964, 54(6), pp. 961-74.

- "Issues in Assessing the Contribution of R\&D to Productivity Growth." Bell Journal of Economics, Spring 1979, 10(1), pp. 92-116. [Reprinted as chap. 2 in this volume.]

__ _ "Productivity, R\&D and Basic Research at the Firm Level in the 1970s." American Economic Review, March 1986a, 76(1), pp. 141-54. [Reprinted as chap. 4 in this volume.]

. "Data Issues in Econometrics," in Z. Griliches and M. Intriligator, eds., Handbook of econometrics. Amsterdam: North-Holland, 1986b, pp. 1466-1514.

- "Productivity Puzzles and R\&D: Another Nonexplanation." Journal of Economic Perspectives, Fall 1988, 2(4), pp. 9-21.

- "Patent Statistics as Economic Indicators: A Survey." Journal of Economic Literature, December 1990, 18(4), pp. 1661-1707. [Reprinted as chap. 13 in this volume.]

- "The Search for R\&D Spillovers." Scandinavian Journal of Economics, Supplement 1991, 94, pp. 29-47. [Reprinted as chap. 11 in this volume.]

- "Introduction," in Z. Griliches, ed., Output measurement in the service sectors, NBER Studies in Income and Wealth, Vol. 56. Chicago: University of Chicago Press, 1992, pp. 1-22.

- "The Discovery of the Residual." Journal of Economic Literature, September 1996, 34, pp. 1324-30.

Griliches, Zvi and Cockburn, Iain A. "Generics and New Goods in Pharmaceutical Price Indexes." American Economic Review, December 1994, 84(5), pp. 1213-32.

Griliches, Zvi and Lichtenberg, Frank. "R\&D and Productivity Growth at the Industry Level: Is There Still a Relationship?" in Zvi Griliches, ed., $R \& D$, patents, and productivity. Chicago: University of Chicago Press, 1984, pp. 465-96. [Reprinted as chap. 9 in this volume.]

- "Errors of Measurement in Output Deflators." Journal of Business and Economic Statistics, January 1989, 7(1), pp. 1-9.

Griliches, Zvi and Mairesse, Jacques. "Productivity and R\&D at the Firm Level," in Zvi Griliches, ed., $R \& D$, patents, and productivity. Chicago: University of Chicago Press, 1984, pp. 339-74. [Reprinted as chap. 5 in this volume.]

Griliches, Zvi and Ringstad, Vidar. Economies of scale and the form of the production function. Amsterdam: North-Holland, 1971.

Grossman, Gene M. and Helpman, E. Innovation and growth in the global economy. Cambridge, MA: MIT Press, 1991.

Hall, Bronwyn H. "Industrial Research during the 1980s: Did the Rate of Return Fall?" Brookings Papers on Economic Activity, Microeconomics, 1993, (2), pp. 289-330. 
Hall, Bronwyn H. and Hall, Robert E. "The Value and Performance of U.S. Corporations." Brookings Papers on Economic Activity, 1993, (1), pp. 1-50.

Harberger, Arnold C. "Reflections on the Growth Process." Unpublished manuscript, University of California, Los Angeles, 1990.

Hendel, Igal. "The Role of PC's in Manufacturing Industries.” Unpublished manuscript, Harvard University, 1993.

Henderson, Rebecca and Cockburn, Iain. "Scale, Scope and Spillovers: The Determinants of Research Productivity in the Pharmaceutical Industry." National Bureau of Economic Research (Cambridge, MA) Working Paper No. 4466, 1993.

Huffman, Wallace E. and Evenson, Robert E. Science for agriculture. Ames, IA: Iowa State University Press, 1993.

Jaffe, Adam; Trajtenberg, Manuel and Henderson, Rebecca. "Geographic Localization of Knowledge Spillovers as Evidenced by Patent Citations." Quarterly Journal of Economics, August 1993, 108(3), pp. 577-98.

Jensen, Michael C. "The Modern Industrial Revolution, Exit, and the Failure of Internal Control Systems." Journal of Finance, July 1993, 48(3), pp. 831-80.

Johnson, Harry G. "Comment on Vaizey," in The residual factor and economic growth. Paris: Organization for Economic Cooperation and Development, 1964, pp. 219-27.

Jorgenson, Dale W. and Fraumeni, Barbara M. "The Output of the Education Sector," in Z. Griliches, ed., Output measurement in the service sectors, NBER Studies in Income and Wealth, Vol. 56. Chicago: University of Chicago Press, 1992, pp. 303-38.

Jorgenson, Dale W. and Griliches, Zvi. "The Explanation of Productivity Change." $R e$ view of Economic Studies, March 1967, 34(3), pp. 249-83.

Juhn, Chinhui; Murphy, K. M. and Pierce, B. "Wage Inequality and the Rise in Returns to Skill." Journal of Political Economy, June 1993, 101(3), pp. 410-42.

Kendrick, John W. Productivity trends: Capital and labor. New York: National Bureau of Economic Research, 1956.

Kleinknecht, Alfred. Innovation patterns in crisis and prosperity. New York: St. Martin's, 1987.

Kortum, Samuel. "Equilibrium R\&D and the Patent-R\&D Ratio: U.S. Evidence." American Economic Review, May 1993 (Papers and Proceedings), 83(2), pp. 450-57.

Krueger, Alan B. "How Computers Have Changed the Wage Structure: Evidence from Microdata, 1984-89." Quarterly Journal of Economics, February 1993, 108(1), pp. 33-60.

Krueger, Alan and Ashenfelter, Orley. "Estimates of the Economic Return to Schooling from a New Sample of Twins." American Economic Review, December 1994, 84(5), pp. 1157-73.

Leibenstein, Harvey. "Allocative Efficiency vs. 'X-Efficiency."' American Economic Review, June 1966, 56(3), pp. 392-415.

Levin, Richard; Klevorick, A.; Nelson, R. and Winter, S. "Appropriating the Returns from Industrial Research and Development." Brookings Papers on Economic Activity, Microeconomics 1987, (3), pp. 783-820.

Lichtenberg, Frank and Siegel, Donald. "The Impact of R\&D Investment on Productivity: New Evidence Using Linked R\&D-LRD Data." Economic Inquiry, April 1991, 29(2), pp. 203-29.

Mairesse, Jacques and Sassenou, Mohamed. "R\&D and Productivity: A Survey of Econometric Studies at the Firm Level." STI Review (OECD, Paris), 1991, 8, pp. 9-43.

Mansfield, E. "Technical Change and the Rate of Imitation." Econometrica, October 1961, 29(4), pp. 741-66. 
. "Rates of Return from Industrial R\&D." American Economic Review, May 1965 (Papers and Proceedings), 55(2), pp. 310-22.

Manski, Charles F. "Identification of Endogenous Social Effects: The Reflection Problem." Review of Economic Studies, July 1993, 60(3), pp. 531-42.

Mensch, Gerhard; Haag, Gunter and Weidlich, Wolfgang. "The Schumpeter Clock," in Technology and productivity. Paris: Organization for Economic Cooperation and Development, 1991, pp. 523-44.

Nadiri, M. I. "Innovations and Technological Spillovers." National Bureau of Economic Research (Cambridge, MA) Working Paper No. 4423, August 1993.

National Academy of Sciences. Measurement and interpretation of productivity. Washington, DC: National Academy Press, 1979.

National Bureau of Economic Research. The price statistics of the federal government, General Series No. 73. New York: National Bureau of Economic Research, 1961.

National Science Board. Science and engineering indicators-1991. Washington, DC: U.S. Government Printing Office, 1991.

National Science Foundation. Research and development in industry: 1989, NSF 92307. Washington, DC: National Science Foundation, 1992.

Nelson, Richard $\mathrm{R}$. The rate and direction of inventive activity. Princeton, NJ: Princeton University Press, 1962.

Nordhaus, William D. "The Recent Productivity Slowdown." Brookings Papers on Economic Activity, 1972, (3), pp. 493-537.

. "Comment on Griliches." Brookings Papers on Economic Activity, Microeconomics 1989, pp. 320-25.

Office of Technology Assessment, U.S. Congress. Statistical needs for a changing U.S. economy, Background Paper OTA-BP-E-58. Washington, DC: U.S. Government Printing Office, 1989.

Olson, Mancur. The rise and decline of nations. New Haven, CT: Yale University Press, 1982.

Organization for Economic Cooperation and Development. OECD Economic outlook, No. 53. Paris: Organization for Economic Cooperation and Development, June 1993.

Pakes, Ariel and Simpson, Margaret. "Patent Renewal Data." Brookings Papers on Economic Activity, Microeconomics 1989, pp. 331-410.

Patel, Pari and Soete, Luc. "Measuring the Economic Effects of Technology." STI Review (OECD, Paris), 1988, 4, pp. 121-66.

Reinsdorf, Marshall. "The Effect of Outlet Price Differentials on the U.S. Consumer Price Index," in M. F. Foss, M. E. Manser, and A. H. Young, eds., Price measurements and their uses, NBER Studies in Income and Wealth, Vol. 57. Chicago: University of Chicago Press, 1993, pp. 227-54.

Romer, Paul M. "Endogenous Technological Change." Journal of Political Economy, October 1990, 98(5), pp. S71-S102.

Ruggles, Richard. The wholesale price index. Washington, DC: Council on Wage and Price Stability, 1977.

Ruttan, Vernon W. Technological progress in the meat packing industry, 1910-47, Marketing Research Report. Washington, DC: U.S. Department of Agriculture, 1954.

- "The Contribution of Technological Progress to Farm Output, 1950-1975." Review of Economics and Statistics, February 1956, 38(1), pp. 61-69.

Schankerman, Mark and Pakes, Ariel. "Estimates of the Value of Patent Rights in European Countries During the Post-1950 Period." Economic Journal, December 1986, 96(384), pp. 1052-76.

Scherer, F. M. "R\&D and Declining Productivity Growth." American Economic Review, May 1983 (Papers and Proceedings), 73(2), pp. 215-18.

- "Using Linked Patent and R\&D Data to Measure Interindustry Technology 
Flows," in Z. Griliches, ed., R\&D, patents, and productivity. Chicago: University of Chicago Press, 1984, pp. 417-64.

- "The World Productivity Growth Slump," in R. Wolff, ed., Organizing industrial development. Berlin: de Gruyter, 1986, pp. 15-27.

__ . "Lagging Productivity Growth: Measurement, Technology and Shock Effects." Empirica, 1993, 20(1), pp. 5-24.

Schmookler, Jacob. "The Changing Efficiency of the American Economy 1869-1938." Review of Economics and Statistics, August 1952, 34(3), pp. 214-31. 1966.

Schultz, Theodore W. Restoring economic equilibrium. Oxford: Blackwell, 1990.

Siegel, Donald and Griliches, Zvi. "Purchased Services, Outsourcing, Computers, and Productivity in Manufacturing," in Z. Griliches, ed., Output measurement in the service sectors, NBER Studies in Income and Wealth, Vol. 56. Chicago: University of Chicago Press, 1992, pp. 429-60.

Solow, Robert M. "Technical Change and the Aggregate Production Function." Review of Economics and Statistics, August 1957, 39(3), pp. 312-20.

- "Growth Theory," in David Greenaway, Michael Bleaney, and Ian Stewart, eds., Companion to contemporary economic thought. London: Routledge, 1991, pp. 393-415.

Stigler, George J. Trends in output and employment. New York: National Bureau of Economic Research, 1947.

Summers, Robert and Heston, Alan. "The Penn World Table (Mark 5): An Expanded Set of International Comparisons, 1950-1988." Quarterly Journal of Economics, May 1991, 106(2), pp. 327-68.

Sveikauskas, L. "Productivity Growth and the Depletion of Technological Opportunities." Journal of Productivity Analysis, June 1990, 1(4), pp. 301-8.

Tinbergen, J. "Zur Theorie der Langfirstigen Wirtschaftsentwicklung," Weltwirtschaftliches Archiv, January 1942, 55(1), pp. 511-49; reprinted in English translation in J. Tinbergen, Selected papers. Amsterdam: North-Holland, 1959.

Tong, X. and Frame, J. D. "Measuring National Technological Performance with Patent Claims Data." Unpublished manuscript, George Washington University, 1992.

Trajtenberg, Manuel. Economic analysis of product innovation: The case of CT scanners. Cambridge, MA: Harvard University Press, 1990a.

_ _ "A Penny for Your Quotes: Patent Citations and the Value of Innovations." Rand Journal of Economics, Spring 1990b, 21(1) pp. 172-87.

Triplett, Jack E. "Price and Technological Change in a Capital Good: A Survey of Research and Computers," in D. W. Jorgenson and R. Landau, eds., Technology and capital formation. Cambridge, MA: MIT Press, 1989, pp. 127-213.

. "The Federal Statistical System's Response to Emerging Data Needs." Journal of Economic and Social Measurement, 1991, 17(3-4), pp. 155-201.

Young, Allan H. "Alternative Measures of Change in Real Output and Prices." Survey of Current Business, April 1992, 72(4), pp. 32-48. 